УДК 005.931.11

JEL Classification: L83, R58

TATAP M. C. 1

\title{
ТЕОРЕТИКО-МЕТОДОЛОГІЧНИЙ БАЗИС СОЦІАЛЬНО-ЕКОНОМІЧНОЇ ВЗАЄМОДІЇ СУБ'ЄКТІВ ГОСПОДАРЮВАННЯ В УМОВАХ ГЛОБАЛЬНИХ ВИКЛИКІВ
}

DOI: $10.32620 /$ cher.2021.1.05

Постановка проблеми. Сучасні глобальні виклики та дисбаланси викликають необхідність співпрацювати у нових реаліях, змінювати характер взаємодії для протидії глобальним викликам шляхом активізації найбільш ефективних форм, методів, типів та механізмів взаємодії та створення нової філософії ціннісних й мотиваційних орієнтирів соціально-економічної взаємодії. Процеси соціально-економічної невизначеності господарських перспектив в умовах глобальних викликів вимагають формування теоретико-методологічного базису взаємодії суб'єктів господарювання. Метою статті $\epsilon$ формування теоретико-методологічного базису соціально-економічної взаємодії суб'єктів господарювання в умовах сучасних глобальних викликів. Предмет дослідження - теоретичні й методологічні аспекти соціально-економічної взаємодії суб'єктів господарювання в умовах глобальних викликів. Методи, використані в дослідженні: історичний метод, методи верифікації теоретичних положень (морфологічний аналіз змісту та взаємозв'язку категорій, принципів та законів, оцінка відповідності історичних фактів теоретичним гіпотезам), методи аналізу і синтезу, індукції і дедукції, логічний метод (гіпотетичний та аксіоматичний підхід), метод порівняння. Гіпотеза дослідження. В умовах глобальних викликів необхідно змінювати характер взаємодії, для чого слід сформувати теоретико-методологічний базис такої взаємодії та визначити напрями необхідних змін у взаємодії. Виклад основного матеріалу. У межах гносеологічного поля дослідження проаналізовано дефініції «взаємодії» як соціальної, економічної, філософської, психологічної та управлінської категорій. Визначено забезпечуючі підсистеми соціально-економічної взаємодії суб'єктів господарювання в умовах глобальних викликів, серед яких виділено й охарактеризовано нормативно-правову, фінансову, матеріально-технічну, кадрову, інформаційну, логістичну, інфраструктурну, психологічну, наукову, інституційну, організаційну забезпечуючі підсистеми. У межах змістовного (парадигмально-методологічного) базису дослідження запропоновано виокремити парадигмальні положення соціально-економічної взаємодії та методологічне підгрунтя дослідження соціально-економічної взаємодії суб'єктів господарювання в умовах глобальних викликів. Оригінальність та практичне значення дослідження. Дослідження соціально-економічної взаємодії суб'єктів господарювання в умовах глобальних викликів включає чотири взаємопов'язані блоки - теоретико-експлейнарний базис взаємодії, змістовний (парадигмально-методологічний), прикладний та управлінський базиси взаємодії суб'єктів господарювання, що комплексно охоплюватиме можливі аспекти взаємодії. Висновки дослідження. У статті розглянуто теоретикометодологічний базис взаємодії суб'єктів господарювання під час глобальних викликів, у межах якого запропоновано реалізацію відповідних логічних блоків. У межах подальшого дослідження планується розробити прикладний базис взаємодії, що передбачатиме діагностико-прогностичне поле соціально-економічної взаємодії суб'єктів господарювання в умовах глобальних викликів та моделювання соціально-економічної взаємодії суб'єктів господарювання, а також управлінський базис взаємодії суб'єктів господарювання, що передбачатиме послідовність етапів управління процесом соціально-економічної взаємодії та визначення ефективності взаємодії згідно перебігу глобальних викликів.

\section{Ключові слова:}

глобальні виклики, гносеологічне поле, забезпечуючі підсистеми, соціально-економічна взаємодія, суб'єкти господарювання, теоретико-методологічний базис

${ }^{1}$ Татар Марина Сергіївна, канд. екон. наук, доцент кафедри фінансів, обліку і оподаткування, Національний аерокосмічний університет ім. М. Є. Жуковського «Харківський авіаційний інститут», м. Харків, Україна.

Tatar Maryna, Ph.D in Economics, Associate professor of the Finance, Accounting and Taxation Department, National Aerospase University «Kharkiv Aviation Institute», Kharkiv, Ukraine.

ORCID ID: 0000-0002-1111-7103

e-mail: marina.sergeevna.tatar@gmail.com 


\section{THEORETICAL AND METHODOLOGICAL BASIS OF SOCIO-ECONOMIC INTERACTION OF BUSINESSES IN THE CONDITIONS OF GLOBAL CHALLENGES}

Formulation of the problem. Modern global challenges and imbalances necessitate cooperation in new realities, change the interaction nature to counter global challenges by activating the most effective forms, methods, types and mechanisms of interaction and creating a new values philosophy and motivational guidelines for socio-economic interaction. The processes of socio-economic uncertainty of economic prospects in the context of global challenges require the formation of theoretical and methodological basis for the economic entities interaction. The aim of the research is formation of theoretical and methodological basis for economic entities socio-economic interaction in the context of modern global challenges. The subject of the research is theoretical aspect and methodological aspect of business entities socio-economic interaction in global challenges context. The methods of the research: historical method, methods of verification of theoretical positions (morphological analysis of the content and interrelation of categories, principles and laws, assessment of historical facts to theoretical hypotheses), methods of analysis and synthesis, induction and deduction, logical method (hypothetical and axiomatic approach), comparison method. The hypothesis of the research. In the context of global challenges, it is necessary to change the nature of interaction, for which it is necessary to form a theoretical and methodological basis for such interaction and determine the directions of necessary changes in interaction. The statement of basic materials. Within the epistemological field of research, the definitions of "interaction" as social, economic, philosophical, psychological and managerial categories are analyzed. The providing subsystems of business entities social and economic interaction in the conditions of global challenges are determined, among which the normative and legal, financial, logistical, personnel, informational, logistic, infrastructural, psychological, scientific, institutional, organizational supporting subsystems are singled out and characterized. Within the content (paradigmatic and methodological) basis of the research, it is proposed to distinguish the paradigmatic provisions of socio-economic interaction and the methodological basis of business entities socio-economic interaction research in the context of global challenges. The originality and practical significance of the research. The research of business entities socio-economic interaction in the context of global challenges includes four interrelated blocks - theoretical and explanatory basis of interaction, content (paradigmatic and methodological), applied and managerial basis of interaction, which complex covers possible interaction aspects. Conclusions and perspectives of further research. The article considers the theoretical and methodological basis of business entities interaction during global challenges, within which the implementation of the relevant logical blocks is proposed. Within the framework of further research it is planned to develop an applied basis of interaction, which will provide a diagnostic and prognostic field of socio-economic interaction in the context of global challenges and modeling of of business entities socio-economic interaction, as well as management basis of interaction of business entities, which will provide a sequence of management stages of the socio-economic interaction process and determine the interaction effectiveness in global challenges.

Key words:

global challenges, epistemological field, supporting subsystems, socio-economic interaction, business entities, theoretical and methodological basis.

\section{ТЕОРЕТИКО-МЕТОДОЛОГИЧЕСКИЙ БАЗИС СОЦИАЛЬНО-ЭКОНОМИЧЕСКОГО ВЗАИМОДЕЙСТВИЯ СУБЪЕКТОВ ХОЗЯЙСТВОВАНИЯ В УСЛОВИЯХ ГЛОБАЛЬНЫХ ВЫЗОВОВ}

Постановка проблемы. Современные глобальные вызовы и дисбалансы вызывают необходимость сотрудничать в новых реалиях, менять характер взаимодействия для противодействия глобальным вызовам путем активизации наиболее эффективных форм, методов, типов и механизмов взаимодействия и создания новой философии ценностных и мотивационных ориентиров социально-экономического взаимодействия. Процессы социально-экономической неопределенности хозяйственных перспектив в условиях глобальных вызовов требуют формирования теоретико-методологического базиса взаимодействия субьетив хозяйствования. Целью статьи является формирование теоретикометодологического базиса социально-экономического взаимодействия субъектов хозяйствования в условиях современных глобальных вызовов. Предмет исследования - теоретические и методологические аспекты социально-экономического взаимодействия субъектов хозяйствования в условиях глобальных вызовов. Meтоды, используемые в исследовании: исторический метод, методы верификации теоретических положений (морфологический анализ содержания и взаимосвязи категорий, принципов и законов, оценка соответствия исторических фактов теоретическим гипотезам), методы анализа и синтеза, индукции и дедукции, логический метод (гипотетический и аксиоматический подходы), метод сравнения. Гипотеза исследования. В условиях глобальных вызовов необходимо менять характер взаимодействия, для чего следует сформировать теоретико-методологический базис такого взаимодействия и определить направления необходимых изменений во взаимодействии. Изложение 
основного материала. В рамках гносеологического поля исследования проанализированы дефиниции «взаимодействия» как социальной, экономической, философской, психологической и управленческой категорий. Определены обеспечивающие подсистемы социально-экономического взаимодействия субъектов хозяйствования в условиях глобальных вызовов, среди которых выделены и охарактеризованы нормативно-правовая, финансовая, материально-техническая, кадровая, информационная, логистическая, инфраструктурная, психологическая, научная, институциональная, организационная обеспечивающие подсистемы. В рамках содержательного (парадигмально-методологического) базиса исследования предложено выделить парадигмальные положения социально-экономического взаимодействия и методологическое основание исследования социально-экономического взаимодействия субъектов хозяйствования в условиях глобальных вызовов. Оригинальность и практическое значение исследования. Исследование социально-экономического взаимодействия субъектов хозяйствования в условиях глобальных вызовов включает четыре взаимосвязанных блока - теоретико-експлейнарний базис взаимодействия, содержательный (парадигмально-методологический), прикладной и управленческий базис взаимодействия субъектов хозяйствования, что позволит комплексно охватывать возможные аспекты взаимодействия. Выводы исследования. В статье рассмотрен теоретико-методологический базис взаимодействия субъектов хозяйствования при глобальных вызовах, в рамках которого предложено реализацию соответствующих логических блоков. В рамках дальнейшего исследования планируется разработать прикладной базис взаимодействия, предусматривающий диагностико-прогностическое поле социально-экономического взаимодействия субъектов хозяйствования в условиях глобальных вызовов и моделирование социально-экономического взаимодействия субъектов хозяйствования, а также управленческий базис взаимодействия субъектов хозяйствования, предусматривающий последовательность этапов управления процессом социально-экономического взаимодействия и определение эффективности взаимодействия исходя из протекания глобальных вызовов.

\section{Ключевые слова:}

глобальные вызовы, гносеологическое поле, обеспечивающие подсистемы, социальноэкономическое взаимодействие, субъекты хозяйствования, теоретико-методологический базис.

Постановка проблеми. Сучасні глобальні виклики та дисбаланси викликають необхідність співпрацювати у нових реаліях, змінювати характер взаємодії для протидії цим викликам шляхом активізації найбільш ефективних форм, методів, типів й механізмів взаємодії та створення нової філософії ціннісних і мотиваційних орієнтирів соціально-економічної взаємодії. Процеси соціально-економічної невизначеності господарських перспектив в умовах глобальних викликів вимагають формування теоретико-методологічного базису взаємодії суб' єктів господарювання.

Аналіз останніх досліджень i публікацій. Дослідженню різних аспектів взаємодії суб'єктів господарювання присвячені роботи таких дослідників як Фещур Р. В. [1], Шамаєва Л.Г. [2], Шевук Є.В. [3], Яворська Н. P. [1], та багатьох інших. Шевук Є.В. обгрунтовує поняття «взаємодія» як економічної та управлінської категорії [3, с. 16]. Фещур Р.В., Тимощук М.Р., Яворська Н.P., Якимів А.I. розкривають сутність методологічного базису соціально-економічної взаємодії суб'єктів господарювання 3 навколишнім, внутрішнім і зовнішнім середовище [1, с. 290].

У процесі взаємодії кожна сторона прагне досягнути поставлену перед нею мету: навколишнє середовище - зберегти екосистему; внутрішнє середовище - забезпечити економічний розвиток підприємства 3 дотриман- ням положень щодо соціально відповідальної діяльності; зовнішнє середовище - урівноважити економічні та соціальні інтереси.

Наявність зв'язків є важливою характеристикою економіко-виробничої системи, через які узгоджуються як комплементарні, так і суперечливі інтереси стейкхолдерів (заінтересованих сторін). Розв'язання протиріч, що виникають між ними, відбувається у процесі соціально-економічної взаємодії підприємств із навколишнім, внутрішнім і зовнішнім середовищем та сприяє досягненню встановлених внутрішніх цілей кожної сторони [1, с. 286-287]

Більшість дослідників виділяють типові сфери застосування терміну «взаємодія» як соціально-економічної категорії: взаємодія суб'єктів господарювання та суспільства; взаємодія суб'єктів господарювання 3 клієнтами; взаємодія $з$ контрагентами (банками, сраховими компаніями тощо); взаємодія держави та суб'єктів господарювання; взаємодія конкурентів.

Незважаючи на вагомі внески науковців у дослідження проблематики взаємодії суб'єктів господарювання 3 зовнішнім середовищем, недостатньо розглянуто нагальну в сучасних умовах проблему зміни характеру взаємодії суб'єктів господарювання в умовах сучаних глобальних викликів, ідентифікація i класифікація яких представлена у роботі [4, с. 40]. 
Метою статті є формування теоретикометодологічного базису соціально-економічної взаємодії суб'єктів господарювання в умовах сучасних глобальних викликів.

Виклад основного матеріалу дослідження. Дослідження соціальноекономічної взаємодії суб'єктів господарювання в умовах глобальних викликів включає чотири взаємопов'язані блоки - теоретикоексплейнарний базис взаємодії, змістовний (парадигмально-методологічний), прикладний та управлінський базис взаємодії суб'єктів господарювання (рисунок 1).

Блок 1. Теоретико-експлейнарний базис взаємодії суб'єтів господарювання, зміст якого наведено на рисунок 2, включає дослідження гносеологічного поля соціально-економічної взаємодії суб'єктів господарювання та забезпечуючих підсистем соціально-економічної взаємодії суб'єктів господарювання в умовах глобальних викликів.

\section{Блок 1. Теоретико-експлейнарний базис взаємодії}

Гносеологічне поле соціально-економічної взаємодії суб’єктів господарювання

Забезпечуючі підсистеми соціально-економічної взаємодії суб’єктів господарювання

\section{Блок 2. Змістовний (парадигмально-методологічний) базис взаємодії}

Парадигмальні положення соціально-економічної взаємодії суб’єктів господарювання в умовах глобальних викликів

Методологічне підгрунтя дослідження соціально-економічної взаємодії суб’єктів господарювання в умовах глобальних викликів

\section{Блок 3. Прикладний базис взаємодії}

Діагностико-прогностичне поле соціально-економічної взаємодії суб'єктів господарювання в умовах глобальних викликів

Моделювання соціально-економічної взаємодії суб'єктів господарювання в умовах глобальних викликів

\section{Блок 4. Управлінський базис взаємодії}

Управління процесом соціально-економічної взаємодії суб'єктів господарювання в умовах глобальних викликів

Визначення ефективності взаємодії суб'єктів господарювання згідно перебігу глобальних викликів

Рисунок 1 - Послідовність дослідження соціально-економічної взаємодії суб'єктів господарювання в умовах глобальних викликів Джерело: розроблено автором

Гносеологічне поле соціальноекономічної взаємодії суб'єктів господарювання в умовах глобальних викликів $є$ фундаментальною складовою. В процесі пізнання категорії «взаємодії» первинно мають визначатися iї дефініції як соціальної, економічної, філософської, психологічної та управлінської категорії (таблиця 1). 

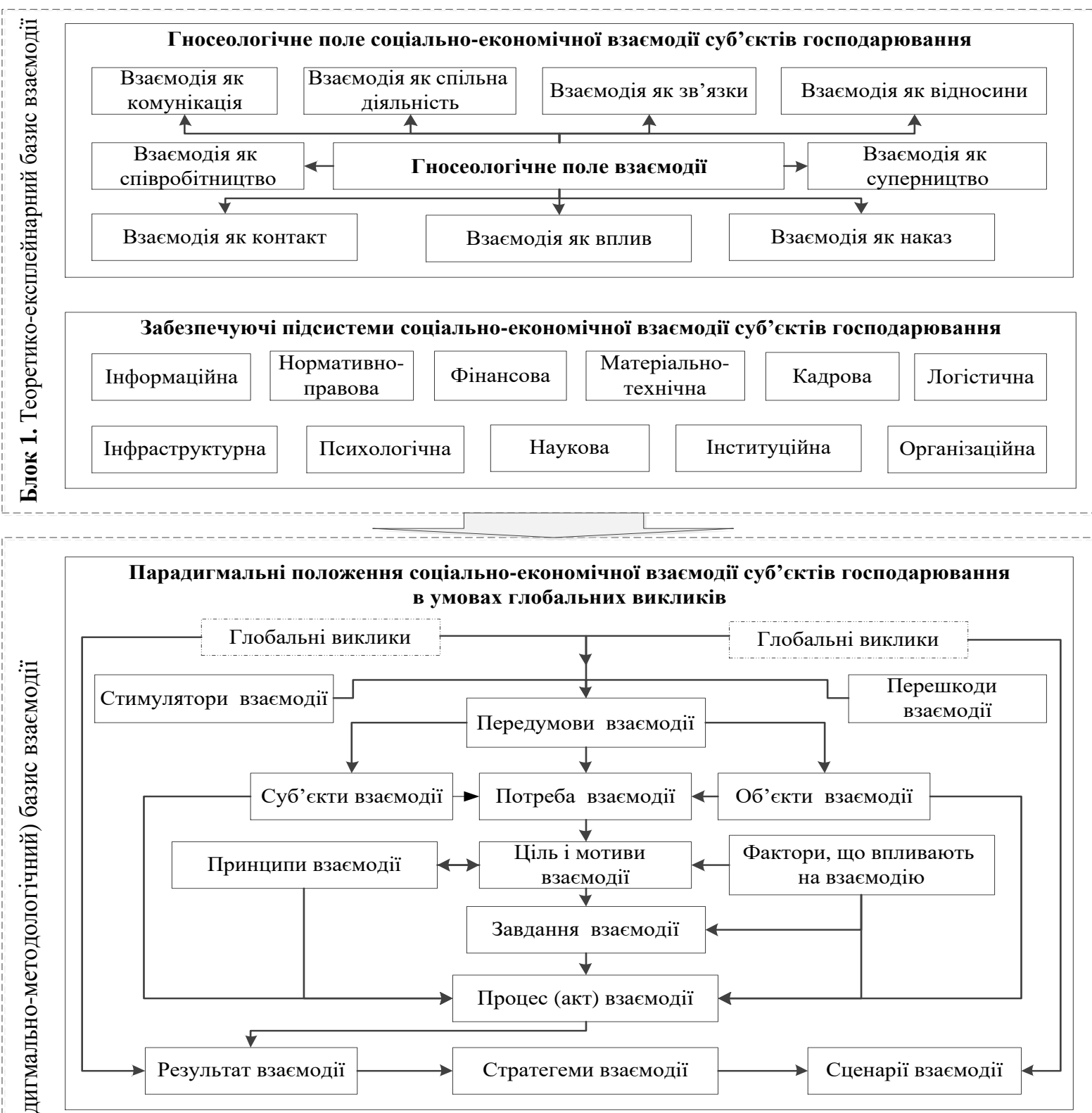

Методологічне підгрунтя дослідження соціально-економічної взаємодії суб'єктів господарювання в умовах глобальних викликів

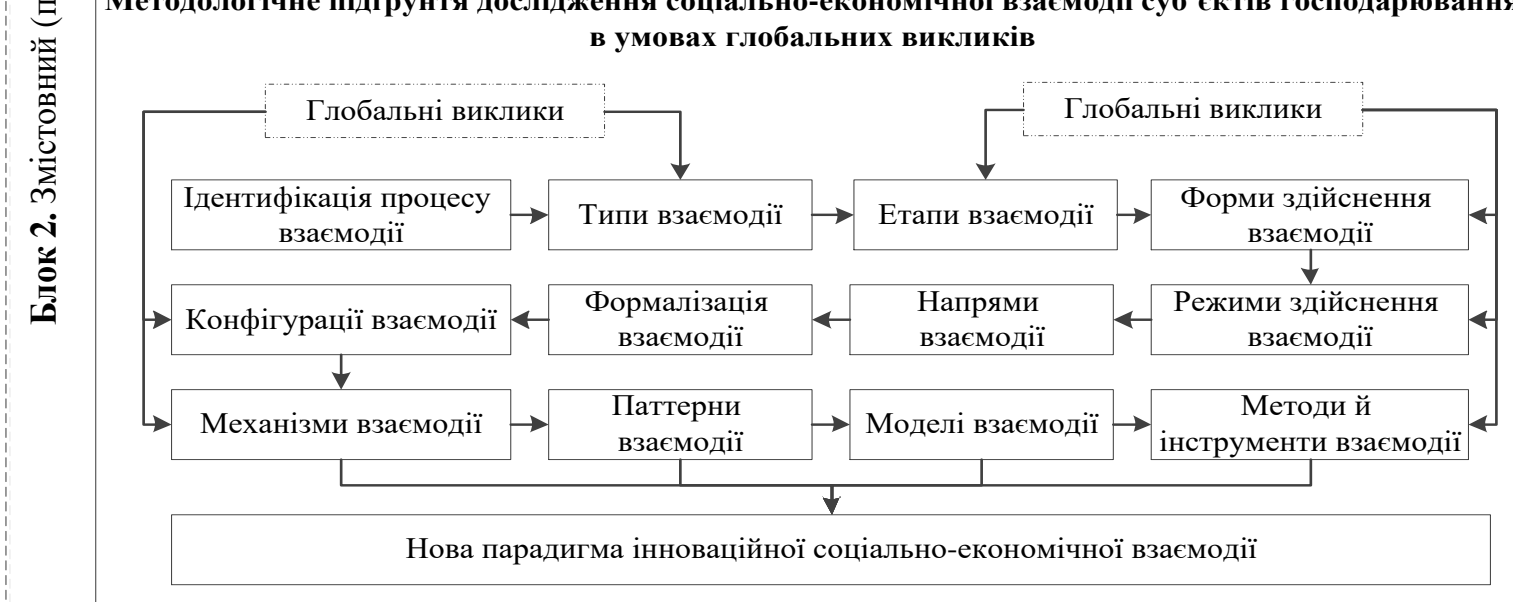

Рисунок 2 - Теоретико-експлейнарний та змістовний базиси взаємодії суб'єктів господарювання в умовах глобальних викликів Джерело: розроблено автором 
Таблиця 1 - Дефініції взаємодії як соціальної, економічної, управлінської, філософської, психологічної категорії

\begin{tabular}{|c|c|}
\hline Дефініція & Автори \\
\hline 1 & 2 \\
\hline $\begin{array}{l}\text { Взаємодія - категорія, що відображає процеси впливу об'єктів один на одного, їх } \\
\text { взаємну обумовленість і породження одним об'єктом іншого. }\end{array}$ & $\begin{array}{c}\text { Словник термінів } 3 \\
\text { філософї [5] }\end{array}$ \\
\hline $\begin{array}{l}\text { Взаємодія - сукупність процесів впливу різних об’єктів один на одного, їхня } \\
\text { взаємозумовленість та зміна стану чи взаємоперехід, а також породження одним } \\
\text { об’єктом іншого. Якості об’єкта можуть проявитися і бути пізнаними лише у } \\
\text { взаємодії з іншими об’єктами. Взаємодія є інтегруючим фактором, за допомогою } \\
\text { якого відбувається поєднання частин у певний тип цілісності - структуру. }\end{array}$ & $\begin{array}{l}\text { Словник українсь- } \\
\text { кої мови [6, с. } 121]\end{array}$ \\
\hline $\begin{array}{l}\text { Взаємодія - процес впливу об’єктів один на одного, що визначає їхню взаємоз- } \\
\text { умовленість і зв’язок }\end{array}$ & $\begin{array}{l}\text { Дьяченко М. } \\
{[7, \text { с. } 54]}\end{array}$ \\
\hline $\begin{array}{l}\text { Взаємодія - об'єктивна і універсальна форма руху, розвитку, яка визначає } \\
\text { існування і структурну організацію будь-якої матеріальної системи, а з втратою } \\
\text { взаємодії система перестає існувати. }\end{array}$ & Бир С. Т. [8, с. 213] \\
\hline $\begin{array}{l}\text { Взаємодія - це універсальна властивість всього існуючого світу речей і явищ у їх } \\
\text { взаємній зміні, впливові одного на ін. ... є особливим видом спільної діяльності } \\
\text { систем чи підсистем, які спрямовані на спільне виконання якоїсь мети. } \\
\text { Взаємодія (або «інтеракція» й вона здебільшого ототожнюється зі взаємодією) - } \\
\text { це система зв'язків і взаємодій між індивідами, соціальними групами, сукупність } \\
\text { усіх соціальних відносин }\end{array}$ & $\begin{array}{l}\text { Москаленко В.В. } \\
{[9, \text { с. } 112]}\end{array}$ \\
\hline $\begin{array}{l}\text { Взаємодія - це процес безпосереднього або опосередкованого впливу суб’єктів } \\
\text { один на одного, що породжує їх взаємну обумовленість і зв’язок. Саме причинна } \\
\text { обумовленість становить головну особливість взаємодії, коли кожна з } \\
\text { взаємодіючих сторін виступає як причина іншої та як наслідок одночасного зво- } \\
\text { ротного впливу протилежної сторони, що визначає розвиток об'єктів та їх струк- } \\
\text { тур. Якщо під час взаємодії виявляєтья протиріччя, то воно виступає джерелом } \\
\text { саморуху і саморозвитку явищ та процесів. Під взаємодією розуміється не тільки } \\
\text { вплив суб'єктів один на одного, але й безпосередня організація їх спільних дій, } \\
\text { що дозволяє реалізувати загальну для суб'єктів діяльність. Взаємодія як ма- } \\
\text { теріальний процес супроводжується передачею матерії, руху і інформації. Воно } \\
\text { відносно, здійснюється з кінцевою швидкістю і в певному просторі-часі. Однак } \\
\text { ці обмеження діють лише для безпосередньої взаємодії. Для опосередкованих } \\
\text { форм взаємодії просторово-часових обмежень не існує }\end{array}$ & $\begin{array}{l}\text { Головин С.Ю. } \\
{[10, \text { с. } 281]}\end{array}$ \\
\hline $\begin{array}{l}\text { Взаємодія - особливий тип відносин між об’єктами, при якому кожний з об’єктів } \\
\text { діє (впливає) на інші об'єкти, приводячи їх до зміни, водночас зазнає дії (впливу) } \\
3 \text { боку кожного з цих об’єктів, що, у свою чергу, зумовлює зміну його стану. Її } \\
\text { фундаментальне значення зумовлено тим, що вся людська діяльність у реально- } \\
\text { му світі, практика, а саме - наше існування і відчуття його реальності - грун- } \\
\text { туються на різноманітних взаємодіях, які людина здійснює і використовує як } \\
\text { засіб пізнання, знаряддя дії, спосіб організації буття }\end{array}$ & $\begin{array}{l}\text { Петровский А. В., } \\
\text { Ярошевский М. Г. } \\
\quad[11, \text { с. } 87]\end{array}$ \\
\hline $\begin{array}{l}\text { Взаємодія - процес взаємного впливу об’єктів один на одного, всякий зв'язок і } \\
\text { стосунки між матеріальними об'єктами і явищами }\end{array}$ & $\begin{array}{c}\text { Андреєва Г.М. } \\
{[12, \text { с. } 24]} \\
\end{array}$ \\
\hline $\begin{array}{l}\text { Взаємодія - вид безпосереднього чи опосередкованого, зовнішнього або } \\
\text { внутрішнього відношення, зв’язку. Властивості об’єкта можуть виявлятися і } \\
\text { бути пізнаних тільки у взаємодії з іншими об'єктами. Взаємодія виступає як } \\
\text { інтегруючий фактор, за допомогою якого відбувається об'єднання частин у } \\
\text { певний тип цілісності, організація структури. Кожна форма руху матерії має } \\
\text { в своїй основі певні типи взаємодії структурних елементів }\end{array}$ & $\begin{array}{l}\text { Щуркова Н. Е. } \\
\quad[13, \text { с. } 65]\end{array}$ \\
\hline $\begin{array}{l}\text { Взаємодія - сукупність процесів впливу різних об’єктів один на одного, їхня } \\
\text { взаємозумовленість та зміна стану чи взаємоперехід, а також породження } \\
\text { одним об'єктом іншого. Якості об’єкта можуть проявитися і бути пізнаними } \\
\text { лише у взаємодії з іншими об’єктами. Взаємодія є інтегруючим фактором, за } \\
\text { допомогою якого відбувається поєднання частин у певний тип цілісності - } \\
\text { структуру }\end{array}$ & $\begin{array}{l}\text { Анцупов А.Я. } \\
\text { [14, с. } 71]\end{array}$ \\
\hline $\begin{array}{l}\text { Взаємодія у соціології - така форма спілкування осіб, соціальних спільнот, } \\
\text { угруповань, за якою систематично здійснюється їх вплив один на одного, } \\
\text { реалізується соціальна дія кожного } 3 \text { партнерів, досягається пристосування } \\
\text { дій одного до дій іншого, спільність у розумінні ситуації, сенсу дій і певний } \\
\text { ступінь солідарності та злагоди між ними }\end{array}$ & $\begin{array}{c}\text { Ібрагімова К. О. } \\
{[15, \text { с. } 40]}\end{array}$ \\
\hline
\end{tabular}


Продовження табл. 1

Взаємодія у психології - це процес безпосереднього або опосередкованого впливу людей один на одного, що породжує їх взаємну обумовленість і зв'язок. Саме причинна обумовленість становить головну особливість взаємодії, коли кожна 3 взаємодіючих сторін виступає як причина іншої та як наслідок одночасного зворотного впливу протилежної сторони, що визначає розвиток об'єктів та їх структур. Якщо під час взаємодії виявляється протиріччя, то воно виступає джерелом саморуху і саморозвитку явищ та процесів. Під взаємодією в психології, зазвичай, розуміється не тільки вплив людей один на одного, але й безпосередня організація їх спільних дій, що дозволяє групі реалізувати загальну для іiі членів діяльність

Джерело: розроблено автором на підставі [5], [6], [7], [8], [9], [10], [11], [12], [13], [14], [15], [16], [17], [18]

У межах гносеологічного поля дослідження пропонується розглядати взаємодію як співробітництво та суперництво, як комунікацію, спільну діяльність, зв'язки, відносини, контакт, вплив, наказ.

Співробітництво передбачає такі дії, які сприяють організації спільної діяльності суб'єктів господарювання, забезпечують іiї успішність, узгодженість, ефективність. Цей вид взаємодії позначають також поняттями «згода», «спільна дія», «кооперація», «пристосування», «асоціація».

Суперництво передбачає дії, які певною мірою розхитують спільну діяльність, створюють перепони на шляху до порозуміння, їх позначають також поняттями «конкуренція», «конфлікт», «опозиція», «дисоціація» [19].
3 психологічної точки зору механізм соціальної взаємодії складається 3 потреби, мотивації і самої дії [19, с. 211].

На думку Корнєва М. Н. взаємодія завжди має інтерсуб' єктивний характер, ознаками якого $є$ : предметність (наявність спільної конкретної мети, що зумовлює спільність дій у ході iii досягнення); ситуативність, або регламентованість конкретними обставинами: тривалістю, інтенсивністю, нормами та правилами взаємодії; рефлективність - можливість для взаємодії бути виявом як суб'єктивних намірів, так і наслідком спільної участі в колективній діяльності; експлікованість - можливість спостереження, реєстрації конкретних дій суб'єктів взаємодії [20, с. 211]. Дефініції терміну «взаємодія» як соціально-економічної категорії представлено в таблиці 2.

Т а б л и ц я 2 - Дефініції взаємодії як соціально-економічної категорії

\begin{tabular}{|c|c|c|}
\hline $\begin{array}{l}\text { Підхід до розкриття } \\
\text { сутності поняття } \\
\text { «взаємодія» } \\
\end{array}$ & $\begin{array}{c}\text { Найбільш характерне визначення поняття } \\
\text { «взаємодія» }\end{array}$ & $\begin{array}{c}\text { Науковці, які підтримували } \\
\text { даний підхід }\end{array}$ \\
\hline $\begin{array}{c}\text { Розгляд взаємодії } \\
\text { через співробітництво } \\
\text { (спільну роботу) }\end{array}$ & $\begin{array}{l}\text { Взаємодія - участь у спільній роботі, діяль- } \\
\text { ності: співробітництво, спільне здійснення } \\
\text { операцій, виконання угод }\end{array}$ & $\begin{array}{l}\text { Азріліян О. М. [21, с. 125], } \\
\text { Мочерний С. В. [22, с. 94], } \\
\text { Райзберг Б. А. [23, с. } 73]\end{array}$ \\
\hline $\begin{array}{l}\text { Розгляд взаємодії } \\
\text { через зв'язки }\end{array}$ & $\begin{array}{l}\text { Взаємодія - взаємний зв'язок між предме- } \\
\text { тами у дії, а також погоджена дія між ким-, } \\
\text { чим-небудь }\end{array}$ & $\begin{array}{l}\text { Дьяченко М. [7], } \\
\text { Щуркова Н. Е. [13], Гордієнко } \\
\text { Д. Д. [24, с. 23]. }\end{array}$ \\
\hline $\begin{array}{l}\text { Розгляд взаємодії } \\
\text { через відносини }\end{array}$ & $\begin{array}{l}\text { Взаємодія - міжособистісні відносини, що } \\
\text { необхідні або можливі у зв'язку } 3 \text { вико- } \\
\text { нуваними діями }\end{array}$ & $\begin{array}{l}\text { Петровский А. В., Ярошевский } \\
\text { М. Г. [11], Пасс К. [25, с. 44] }\end{array}$ \\
\hline $\begin{array}{l}\text { Розгляд взаємодії } \\
\text { через комунікацію }\end{array}$ & $\begin{array}{l}\text { Взаємодія - форма соціальної комунікації } \\
\text { або спілкування, яка являє собою систему } \\
\text { соціальних дій як мінімум між двома осо- } \\
\text { бами, або соціальними спільнотами, або } \\
\text { індивіда та соціальної спільноти }\end{array}$ & $\begin{array}{c}\text { Ібрагімова К. О. [15], Поршнєв } \\
\text { А. Г. [26, с. } 67]\end{array}$ \\
\hline $\begin{array}{l}\text { Розгляд взаємодії } \\
\text { через вплив }\end{array}$ & $\begin{array}{l}\text { Взаємодія - це процес безпосереднього або } \\
\text { опосередкованого впливу суб'єктів один на } \\
\text { одного. }\end{array}$ & $\begin{array}{c}\text { Головин С.Ю. [10], } \\
\text { Крисько В.Г. [16], } \\
\text { Борисова В. В. [27, с. 54], } \\
\text { Парахіна В. М. [28, с. 103], } \\
\text { Смірнов Е. О. [29, с. } 37]\end{array}$ \\
\hline
\end{tabular}


Взаємодія як економічна категорія - це міжособистісні відносини, що виникають у процесі участі в спільній роботі, діяльності, співробітництві, спільному здійсненні операцій чи виконанні угод.

Взаємодія як управлінська категорія спільна діяльність учасників, що заснована на позитивній реакції одного учасника на вплив іншого через побудовану (існуючу) систему зв'язків між ними, що супроводжується проце- сами обміну інформацією (комунікацією) [3, с. $15]$.

Отже, «взаємодію» як соціальноекономічну категорію пропонується розглядати як систему сумісних дій кількох суб'єктів, при якій результат дії одного з них впливає на інші. Основні категорії теоретико-експлейнарного базису соціально-економічної взаємодії наведено в таблиці 3.

Т а б л и ц я 3 - Основні категорії теоретико-експлейнарного базису

\begin{tabular}{|c|c|}
\hline Категорія & сть \\
\hline Система & $\begin{array}{l}\text { 1. Система - сукупність елементів, що взаємодіють між собою. } \\
\text { 2. Система характеризується структурною функцією та відношенням цілісності. } \\
\text { 3. Структура системи задається кількістю елементів і зв’язками між ними, які про- } \\
\text { являються у процесі взаємодії }\end{array}$ \\
\hline Зв'язки & $\begin{array}{l}\text { 1. Зв’язки між структурними елементами системи існують, якщо вони впливають на } \\
\text { їх поведінку. } \\
\text { 2. Зв'язки позначаються на діяльності підприємств у процесі їх взаємодії із середо- } \\
\text { вищем функціонування. } \\
\text { 3. Тяглий, стабільний і довірчий характер налагоджених зв'язків визначає мож- } \\
\text { ливість ефективної взаємодії сторін бізнес-процесу для досягнення встановлених } \\
\text { економічних і соціальних цілей }\end{array}$ \\
\hline Взаємодія & $\begin{array}{l}\text { 1. Взаємодія - взаємний зв'язок із обумовленим впливом одного об’єкта на інший. } \\
\text { 2. Найбільш вагомим фактором впливу на розвиток підприємств є взаємодія між } \\
\text { економічними об'єктами і суб'єктами. } \\
\text { 3. Взаємодія - невід'ємна умова розвитку системи }\end{array}$ \\
\hline $\begin{array}{l}\text { Соціальна } \\
\text { взаємодія }\end{array}$ & $\begin{array}{l}\text { 1. Соціальна взаємодія - вид соціального зв'язку. } \\
\text { 2. Соціальна взаємодія - форма соціальної комунікації, що стрямована на досяг- } \\
\text { нення спільної вигоди }\end{array}$ \\
\hline $\begin{array}{l}\text { Соціально- } \\
\text { економічна } \\
\text { взаємодія }\end{array}$ & $\begin{array}{l}\text { У рамках соціальної взаємодії розрізняють взаємодію економічну ... як основу } \\
\text { взаємодії у сфері надбудови відносин, яка детермінує їх у кінцевому підсумку, за- } \\
\text { знаючи одночасно їх активного впливу через соціальні норми та цінності, } \\
\text { свідомість, діяльність політичних партій та громадських організацій» }\end{array}$ \\
\hline $\begin{array}{l}\text { Корпоративна } \\
\text { соціальна } \\
\text { відповідаль-ність }\end{array}$ & $\begin{array}{l}\text { 1. Корпоративна соціальна відповідальність - вид взаємодії підприємств і суспіль- } \\
\text { ства. } \\
\text { 2. Корпоративна соціальна відповідальність - відповідальність організації за вплив } \\
\text { іiі рішень та діяльності на суспільство, навколишнє середовище через прозору та } \\
\text { етичну поведінку, що сприяє сталому розвитку, зокрема здоров’ю та добробуту } \\
\text { суспільства; враховує очікування заінтересованих сторін; відповідає законодавству, } \\
\text { що застосовується та узгоджується з міжнародними нормами поведінки. }\end{array}$ \\
\hline
\end{tabular}

Джерело: розроблено на підставі [30, с. 182], [31, с. 218], [32, с. 299], [33, с. 312], [34]

2. Забезпечуючі підсистеми соціальноекономічної взаємодії суб'єктів господарювання в умовах глобальних викликів включають нормативно-правову, фінансову, матеріальнотехнічну, кадрову, інформаційну, логістичну, інфраструктурну, психологічну, наукову, інституційну, організаційну забезпечуючі підсистеми:

- інформаційне забезпечення передбачає вільний доступ до економічної, комерційної, статистичної, облікової, фінансової інформації, яка не $є$ комерційною чи державною таємницею й може бути підставою для прийняття рішення щодо взаємодії або зміни суб’єктного складу чи характеру взаємодії;

- нормативно-правове включає формальне закріплення конкретних видів взаємодії суб'єктів господарювання один 3 одним, з громадянами, з банківськими установами, страховими компаніями, державними органами тощо на підставі законів України, постанов ВР України та КМУ, указів президента України, наказів, розпоряджень міністерств і відомств;

- фінансове забезпечення включає різноманітні фонди фінансових ресурсів, необхідні для здійснення взаємодії; 
- матеріально-технічне забезпечення включає наявність відповідних матеріальних i технічних ресурсів, які необхідні для реалізації процесу взаємодії;

- кадрове забезпечення передбачає наявність людських ресурсів при здійсненні взаємодії;

- логістичне забезпечення передбачає логістичне управління потоками за вартісночасовими критеріями в процесі забезпечення взаємодії;

- інфраструктурне забезпечення включає необхідність наявності доріг, портів, систем зв'язку тощо, необхідних для здійснення взаємодії;

- психологічне забезпечення передбачає, що взаємодія здійснюється на підставі волевиявлення взаємодіючих суб'єктів, наявність емоційно-психологічної складової, соціальнопсихологічного клімату, згуртування під час взаємодії, культуру та стиль поведінки під час взаємозв'язків суб'єктів;

- наукове забезпечення процесу взаємодії передбачає наявність знаннєвої бази на підставі якої здійснюється взаємодія між суб'єктами, продукування нових знань, інноваційних, креативних, отриманих в процесі взаємодії, а також безпосередньо взаємодія суб'єктів господарювання $з$ університетами, науково-дослідними інститутами, науковими центрами, науковими установами;

- інституційне забезпечення передбачає наявність відповідних інститутів при здійсненні взаємодії на засадах державно-приватного партнерства, об'єднань підприємств, кластерів підприємств, краудандинг (взаємодія відбувається в мережі Інтернет на спеціалізованих платформах або в соціальних мережах), удосконалення старих та створення нових інститутів під дією впливу глобальних викликів;

- організаційне забезпечення включає сукупність заходів, що проводяться для здійснення взаємодії, а також сукупність документів, що встановлюють організаційну структуру взаємодії.

В процесі реалізації теоретикоексплейнарного базису дослідження використано історичний метод, методи верифікації теоретичних положень (морфологічний аналіз змісту та взаємозв'язку категорій, принципів та законів, оцінка відповідності історичних фактів теоретичним гіпотезам), методи аналізу і синтезу, індукції і дедукції, логічний метод (гіпотетичний та аксіоматичний підхід), метод порівняння тощо.

Блок 2. Змістовний (парадигмальнометодологічний) включає парадигмальні поло- ження соціально-економічної взаємодії суб'єктів господарювання в умовах глобальних викликів та методологічне підгрунтя дослідження соціально-економічної взаємодії суб'єктів господарювання в умовах глобальних викликів.

Парадигмальні положення соціальноекономічної взаємодії суб'єктів господарювання в умовах глобальних викликів. Глобальні виклики можуть призвести як до позитивних зрушень, так і до вкрай негативних наслідків, отже, бути як стимуляторами, так і ускладнюючими факторами (перешкодами) взаємодії, що визначає передумови взаємодії.

Наявність глобальних викликів впливає на прийняття рішення щодо взаємодії i, найголовніше, щодо методів здійснення цієї взаємодії. Процес (акт) взаємодії можна представити у вигляді формули (1):

$$
\text { Суб 'єкт + Потреба }+ \text { Мотив }+ \text { Ціль }+
$$

+ Об'єкm = Процес (акт) взаємодї

Процес взаємодії визначає іï результати, на які також впливають глобальні виклики. На підставі отриманих валідних результатів можна побудувати стратагеми взаємодії і сценарії взаємодії.

Ціль і мотиви взаємодії визначають іï основні принципи. Під принципом взаємодії найчастіше розглядають основне, найзагальніше, вихідне положення, засіб, правило, яке визначає природу та соціальну сутність явища, його спрямованість і найсуттєвіші властивості. Принципи соціально-економічної взаємодії суб'єктів господарювання в умовах глобальних викликів, визначено у попередній роботі Татар М. С. [35], серед яких виділено і охарактеризовано принцип спільності та зворотнього зв'язку; відкритості та прозорості; відповідальності, принцип професіоналізму та результативності; соціальної справедливості та корпоративної відповідальності; концентрації на короткостроковому плануванні та перенесення деяких питань 3 довгострокового на короткострокове планування; принцип стратегічності та внесення змін в довгострокові стратегії розвитку; принцип етичності; інноваційності та креативності взаємодії; принцип глобальності та глобальної безпеки; принцип системності та плюралізму; толерантності та включення; інтегральності; принцип зміни усталених зв'язків внаслідок глобальної політичної нестабільності; принцип глобальної спільності; динамічності; закладання більшого рівня ризику; дотримання норм 3 охорони навколишнього природного середовища та принцип мінімізації конфліктів та інституціоналізації компромісів під час взаємодії. 
Методологічне підгрунтя дослідження соціально-економічної взаємодії суб'єктів господарювання в умовах глобальних викликів. За рахунок визначення впливу глобальних викликів на різні складові процесу взаємодії (типи, етапи, форми, режими здійснення взаємодії, напрями, конфігурації, механізми, паттерни, моделі, методи й інструменти), що призводить до зміни складових та процесу взаємодії в цілому, відповідно, має визначатися методологія впливу глобальних потрясінь на зміну соціально-економічної взаємодії суб'єктів господарювання.

Під ідентифікацією процесу взаємодії будемо розуміти констатацію факту наявності взаємодії або наміру взаємодіяти у конкретних суб'єктів господарювання.

Під типами взаємодії розуміються два протилежних типи взаємодії -співробітництво (співпраця) та суперництво, коли просування кожного 3 партнерів до своєї мети сприяє або, як мінімум, не перешкоджає реалізації цілей решти; суперництво (конкуренцію), коли досягнення мети одним із взаємодіючих суб' єктів ускладнює або виключає здійснення цілей інших учасників спільної дії, а також взаємодія під час благодійності, оскільки вона не передбачає матеріальної вигоди для одного 3 суб'єктів взаємодії.

Під етапами взаємодії будемо розуміти конкретні дії, спрямовані на отримання проміжних результатів після завершення кожного етапу взаємодії та кінцевого результату взаємодії.

Формами здійснення взаємодії в умовах глобальних викликів $\epsilon$ електронна форма взаємодії та ведення бізнесу з використанням Інтернет-технологій для забезпечення інформаційної взаємодії суб'єктів господарювання один 3 одним, 3 органами виконавчої влади, 3 населенням; документальна, яка передбачає відправлення контрагентам друкованих документів (найчастіше, підписаних й скріплених печатками); особиста реальна оффлайн взаємодія, що передбачає особистісний контакт 3 взаємодіючим суб'єктом, наявність емоційнопсихологічної взаємодії сторін тощо.

Режим здійснення взаємодії в умовах глобальних викликів може передбачати або інтенсифікацію взаємодії в період глобальних потрясінь, коли деякі підприємства або працюють у дві-три зміни, або збільшують тривалість робочого дня, а отже, й змушені взаємодіяти з іншими суб'єктами в більш інтенсивному режимі, або редукцію взаємодії, коли підприємства в період глобальних потрясінь переводять працівників, наприклад, на
2/3 або 3/4 робочого дня, або надають відпустку без збереження заробітної плати.

Напрями взаємодії передбачають горизонтальну взаємодію, тобто коли суб'єкти знаходяться на одному соціально-економічному та ієрархічному рівні, або вертикальну взаємодію між суб' єктами господарювання та суб'єктами владних повноважень, яким вони підконтрольні та підзвітні (низхідна і висхідна взаємодія). При цьому у низхідній взаємодії управлінські впливи реалізуються шляхом наказів, розпоряджень, приписів тощо, а висхідний взаємозв'язок забезпечує передачу інформації різного функціонального призначення, на кшталт сигналів про виникнення проблемної ситуації та можливих шляхів ii вирішення, надання офіційних звітів тощо.

Формалізація взаємодії передбачає офіційне чи неофіційне оформлення взаємодії між суб'єктами господарювання, тобто офіційне оформлення взаємовідносин, результатом чого $є$ укладення відповідних договорів, a також неформальні домовленості між взаємодіючими суб'єктами, що інколи передбачає наявність корупційних схем взаємодії.

Конфігурації взаємодії (за аналогією конфігураційної взаємодії у квантовій електродинаміці), коли визначається витрачена енергія на здійснення взаємодії елементів, отже передбачається визначення витрачених сил, грошових ресурсів, часу суб' єктів господарювання на налогодження й здійснення взаємодії.

Під механізмом взаємодії будемо розуміти сукупність конкретних дій суб'єктів взаємодії під час здійснення співпраці для досягнення конкретного результату за допомогою спеціальних методів, засобів та інструментів. Розробка механізмів взаємодії обумовлена тим, що необхідно удосконалити взаємовідносини суб'єктів господарювання один 3 одним, 3 органами державної влади й місцевого самоврядування, регіональними громадами та населенням для протидії глобальним викликам, для чого, відповідно, мають бути визначені нові форми такої співпраці, створені умови, що сприятимуть подальшому розвитку суб'єктів господарювання в непередбачуваному або складно передбачуваному зовнішньому середовищі.

Паттерни взаємодії - повторювані шаблонні дії, які виникають й використовуються при схожих початкових умовах взаємодії, що передбачає набір стереотипних поведінкових реакцій або послідовностей дій суб'єктів господарювання в процесі взаємодії в умовах глобальних викликів.

Моделі взаємодії - логічно неспростовне математичне представлення взаємодії суб'єктів 
і об'єктів в умовах глобальних викликів. Наразі для визначення й прогнозування реакції на глобальні виклики використовуються переважно часткові моделі, що моделюють вплив викликів та криз лише в якомусь конкретному аспекті, наприклад, інформаційному, економічному, соціальному, культурному, геополітичному. Проте, як показує досвід «арабської весни», «кризи доткомів DOTCOM», пандемії COVID19 , неможливо розглядати й моделювати подальші дії або наслідки лише в одному напрямку. Зокрема, пандемію COVID-19 хоч і віднесено до групи біологічних глобальних викликів, однак вона вплинула на всі аспекти життя суспільства, на економічну, соціальну, культурну, інформаційну та інші сфери.

Методи взаємодії передбачають спосіб досягнення мети взаємодії, сукупність принципів, правил, прийомів взаємодії, а інструменти визначають за допомогою чого, за допомогою яких інструментів досягається взаємодія.

Висновки та перспективи подальших досліджень. У статті розглянуто теоретикометодологічний базис взаємодії суб'єктів господарювання під час глобальних викликів, у межах якого запропоновано реалізацію відповідних логічних блоків, що дозволить комплексно та всебічно дослідити теоретичні й методологічні аспекти взаємодії суб'єктів господарювання в умовах глобальних викликів. У межах подальшого дослідження планується розробити прикладний базис взаємодії суб'єктів господарювання, що включатиме діагностикопрогностичне поле та моделювання соціальноекономічної взаємодії суб'єктів господарювання, а також управлінський базис взаємодії суб'єктів господарювання, що передбачатиме послідовність етапів управління процесом соціально-економічної взаємодії суб'єктів господарювання та визначення ефективності взаємодії згідно перебігу глобальних викликів.

\section{Література}

1. Фещур Р. В., Тимощук М. Р., Яворська Н.Р. Теоретико-прикладні засади соціально-економічної взаємодії підприємств. Науковий вісник Ужгородського університету. Серія Економіка. 2016. Випуск 1 (47). Т.1. C. 286-292.

2. Шамасва Л. Г. Управління стратегічною взаємодією підприємства із суб' єктами зовнішнього середовища. Наукові прачі ДонНТУ. Серія: Економічна. 2008. Випуск 33-2. С. 50-55.
3. Шевчук Є.В. Детермінація поняття «взаємодія» як економічної та управлінської категорії. Бізнес Інформ. 2018. 7. 14-19.

4. Татар М. С. Ідентифікація та класифікація глобальних викликів. Часопис економічних реформ. 2020. № 3 (39). С. 3644.

5. Словник термінів 3 філософії [Електронний ресурс]. - Режим доступу до сторінки

http://uadoc.zavantag.com/text/29544/index-

1.html

6. Словник української мови. Т.5. Київ: Наукова думка, 1974. 840 с.

7. Дьяченко М., Кандыбович Л., Дьяченко М. Психологический словарьсправочник. Москва, 2001. С. 54-55.

8. Бир С. Т. Кибернетика и менеджмент. Пер. с англ. В.Я. Алтаева; под ред. А.Б. Челюсткина. [изд. 2-е]. Москва: «КомКнига», 2006. $280 \mathrm{c}$.

9. Москаленко В. В. Психологія сочіального виливу: навч. посібник. Київ: Центр учбової літератури, 2007. 448 с.

10. Головин С. Ю. Словарь психолога-практика. Минск: Харвест, 2003. 976 с.

11. Психологический словарь / под общ. ред. А. В. Петровского, М. Г. Ярошевского. 5-е изд., испр. и доп. Москва: Знание. $513 \mathrm{c}$.

12. Андреева Г. М. Социальная психология. Москва: МГУ, 1980. 250 с.

13. Щуркова Н. Е. Школа и семья: педагогический альянс. Москва: Педагогическое общество России, 2004. 112 с.

14. Анцупов А. Я. Словарь конфликтолога. СГЖ: Питер, 2006. - 528 с.

15. Ібрагімова К.О. Дефініція поняття соціальна взаємодія, іiі види та основні теорії. Проблеми інженерно-педагогічної освіти. 2013 . № 40-41 http://library.uipa.edu.ua/images/data/zbirnik/4041/48.pdf

16. Крысько В.Г. Социальная психология: курс лекций. 3-е изд. Москва: Омега-Л, 2006. $352 \mathrm{c}$.

17. Кожушко С. Взаємодія як філософське й психологічне поняття. Освіта регіону. 2013.4 https://socialscience.uu.edu.ua/article/1221

18. Андрощук I. В. Взаємодія як педагогічна категорія. Педагогічний дискурс. 2013. Вип. 14. С. 15-19. Режим доступу: http://nbuv.gov.ua/UJRN/peddysk_2013_14_5 
19. Філоненко М. М. Пихологія спілкування. Режим доступу: https://pidru4niki.com/19991130/psihologiya/psi hologiya_spilkuvannya

20. Корнєв М. Н., Коваленко А. Б. Сочіальна психологія: Підручник. Київ: АТ „Київська книжкова фабрика”, 1995. 304 с.

21. Большой экономический словарь / Под редакцией А. Н. Азрилияна. 6-е изд., доп. Москва: Институт Новой экономики, 2004. $1376 \mathrm{c}$.

22. Економічний енциклопедичний словник : у 2-х т. / за ред. С. В. Мочерного та ін. Львів : Світ, 2005. Т. 1: А - Н. 2005. 616 с.

23. Райзберг Б. А., Лозовский Л. Ш., Стародубцева Е. Б. Современный экономический словарь. 2-е изд., испр. Москва: ИНФРА-М, 1999. 479 с.

24. Економічний тлумачний словник: Понятійна база законодавства Украӥни у сфері економіки / упоряд. Д. Д. Гордієнко. Київ : КНТ, 2006. 308 с.

25. Пасс К., Лоуз Б., Дэвис Л. Словарь по экономике / пер. с англ. СанктПетербург: Эконом. школа, 2004. 752 с.

26. У Уравление организацией: энцииклопедический словарь / под ред. Поршнева А. Г., Кибанова А. Я., Гунина В. Н. Мщсква: ИНФРА-М, 2001. $822 \mathrm{c}$.

27. Борисова В. В., Ларионов В. Г., Мазурин Э. Б. Теория организащии: учебник / под ред. С. Г. Фалько. Москва: Дашков и К은 2014. $308 \mathrm{c}$.

28. Парахина В. Н., Федоренко Т. М., Шацкая Е. Ю. Теория организаџии : учебник 6-е изд. перераб. Москва: КНОРУС, 2014. $360 \mathrm{c}$.

29. Смирнов Э. А. Теория организации : учебное пособие. Москва: ИНФРА-М, 2003. $248 \mathrm{c}$.

30. Економічна енциклопедія : у 3 т. / гол. ред. Б. Д. Гаврилишин. Київ: Академія, 2000. Т. 1 : А (абандон) - К (концентрація виробництва) / відп. ред. С. В. Мочерний. 2000. C. 182.

31. Економічний енциклопедичний словник : у 2 т. / С. В. Мочерний [та ін.] ; ред. С. В. Мочерний. Львів : Світ, 2005. Т. 2 : О Я. Львів : 2006. 563 с.

32. Тєлєтов О. С., Летуновська Н. Є. Взаємодія промислових підприємств та органів місцевого самоврядування в контексті управління соціальною інфраструктурою. Маркетингові інновації в економіці $і$ бізнесі : [колект. монографія / за заг. ред. С. В. Ко- вальчук]. Хмельницький : Поліграфіст-2, 2013. C. 299-309.

33. Туленков М. В. Теоретикометодологічні основи організаційної взаємодії в сочіальному управлінні : монографія. Київ: Каравела, 2012. 512 с.

34. International Standard ISO 26000 Guidance on social responsibility. 2010. 106 pp.

35. Татар М. С. Принципи соціальноекономічної взаємодії суб'єктів господарювання в умовах глобальних викликів. Вісник Одеського начіонального університету. Економіка. 2021. №26, 1(86). С. 28-42.

\section{References}

1. Feshchur, R. V., Tymoshchuk, M. R., Yavorska, N. R. (2016). Theoretical and applied principles of socio-economic interaction of enterprises. Scientific Bulletin of Uzhhorod University. Economics series, 1 (47), 286-292.

2. Shamaieva, L. H. (2008). Management of strategic interaction of the enterprise with the subjects of the external environment. Scientific papers of DonNTU. Economic Series, 33-2, 50-55.

3. Shevchuk, Ye. V. (2018). Determination of the concept of "interaction" as an economic and managerial category. Business Inform, 7, 14-19.

4. Tatar, M. S. (2020). Identification and classification of global challenges. Chasopys of Economic Reforms, 3 (39), 36-44.

5. Dictionary of terms from philosophy. Retrieved from: http://uadoc.zavantag.com/text/29544/index1.html

6. Dictionary of the Ukrainian language (1974). Scientific thought, 840.

7. Diachenko, M. (2001). Psychological dictionary-reference book, 54-55.

8. Byr, S. T. (2006). Cybernetics and management / red. A.B. Cheliustkyna. Moscow: «KomKnyha», 280.

9. Moskalenko, V. V. (2007). Psychology of social influence. Kyiv, 448.

10. Holovyn, S. Yu. (2003). Dictionary of psychologist-practitioner. Minsk: Kharvest, 976.

11. Psychological dictionary. Moscow: Znanye, 513.

12. Andreeva, H. M. (1980). Social psychology. Moscow: MHU, 250. 
13. Shchurkova, N. E. (2004). School and family: pedagogical alliance. Pedagogical Society of Russia, 112.

14. Antsupov, A. Ya. (2006). Dictionary of conflictology. SHZh: Pyter, 528.

15. Ibrahimova, K. O. (2013). Definition of social interaction, its types and basic theories. Problems of engineering and pedagogical education, 40-41. Retrieved from: URL:http://library.uipa.edu.ua/images/data/zbirn ik/40-41/48.pdf

16. Krysko, V. H. (2006). Social psychology. Moscow: Omeha-L, 352.

17. Kozhushko, S. (2013). Interaction as a philosophical and psychological concept. Osvita rehionu. Retrieved from: https://socialscience.uu.edu.ua/article/1221

18. Androshchuk I. V. (2013). Interaction as a pedagogical category. Pedagogical discourse, 14, 15-19. Retrieved from: http://nbuv.gov.ua/UJRN/peddysk_2013_14_5

19. Filonenko, M. M. Psychology of communication. Retrieved from: https://pidru4niki.com/19991130/psihologiya/psi hologiya_spilkuvannya

20. Korniev, M. N. (1995). Social Psychology. Kyiv, 304.

21. Big economic dictionary. (2004). Moscow: Institute of New Economy, 1376.

22. Economic encyclopedic dictionary. (2005). Lviv : Svit, 616.

23. Raizberh, B. A., Lozovskyi, L. Sh., Starodubtseva, E. B. (1999). Modern economic dictionary. Moscow: YNFRA-M, 479.

24. Economic Glossary: Conceptual framework of Ukrainian legislation in the field of economics (2006). D. D. Hordiienko. Kyiv : KNT, 308.

\footnotetext{
Стаття надійшла

до редакції : 15.10 .2020 p.
}

25. Pass, K., Louz, B., Devys, L. (2004). Dictionary of Economics. SanctPeterburg: Economic school, 752.

26. Organization management: an encyclopedic dictionary. (2001). Porshneva A. H., Kybanova A. Ya., Hunyna V. N. Moscow: YNFRA-M, 822.

27. Borysova, V. V., Laryonov, V. H., Mazuryn, E. B. (2014). Organization theory: Moscow: Dashkov y K ${ }^{\circ}, 308$.

28. Parakhyna, V. N., Fedorenko, T. M., Shatskaia, E. Yu. (2014). Organization theory. Moscow: KNORUS, 360.

29. Smyrnov, E. A. (2003). Organization theory. Moscow: YNFRA-M, 248.

30. Havrylyshyn, B. D. (2000). Economic encyclopedia. Kyiv: Academy.

31. Mochernyy, S. V. (2006). Economic encyclopedic dictionary, 2. Lviv: Svit.

32. Tyelyetov, O. S., Letunovska, N. Ye. (2013). Interaction between industry enterprises and local authorities in the context of social infrastructure management. Marketing innovations in the economy and business, 299309.

33. Tulenkov M. V. (2012). Theoretical and methodological foundations of organizational interaction in social management. Kyiv: Karavela.

34. International Standard ISO 26000. (2010). Guidance on social responsibility, 106.

35. Tatar, M. S. (2021). Principles of socio-economic interaction of economic entities in the context of global challenges. Bulletin of Odessa National University. Economy, 26, 1(86), 28-42.

\footnotetext{
Стаття прийнята

до друку: 30.03.2021p.
}

\section{Бібліографічний опис для цитування :}

Татар М. С. Теоретико-методологічний базис соціально-економічної взаємодії суб'єктів господарювання в умовах глобальних викликів / М. С. Татар // Часопис економічних реформ. 2021. - № 1 (41). - С. 37-49. 